\title{
INFLUENCIA DE ASFALTENOS Y RESINAS EN LA VISCOSIDAD DE PETRÓLEOS BITUMINOSOS UTILIZABLES COMO PINTURAS ASFÁLTICAS DE IMPRIMACIÓN
}

\author{
EFFECT OF ASPHALTENE AND RESIN OILS ON THE VISCOSITY \\ OF BITUMINOUS PETROLEUM MATERIALS TO BE USED AS \\ ASPHALT PRIMERS
}

\author{
G. MÁRQUEZ(*), F. J. ALEJANDRE(*), M. R. BENCOMO(**)
}

Recepción/Received: 3-III-05

Aceptación/Accepted: 6-V-05

RESUMEN

Los crudos extrapesados procedentes del área Machete (Venezuela) son materiales de consistencia blanda o fluida, por lo que se salen del campo en el que normalmente se aplica el ensayo de penetración a productos asfálticos según el método ASTM D-5 (1), cuyo límite máximo es $30 \mathrm{~mm}$, y pueden ser utilizados como pinturas asfálticas de imprimación. Al igual que otros productos asfálticos, estos petróleos son químicamente una mezcla de numerosos hidrocarburos nafténicos, parafínicos, aromáticos y compuestos heterocíclicos que contienen azufre, nitrógeno, oxígeno, etc. Están compuestos por una fase pesada y otra de aceites malténicos que, además de los hidrocarburos naturales empleados como aditivos, actúa a modo de fluidificante volátil. La primera fase se describe como una mezcla de asfaltenòs o sustancias complejas de alto peso molecular, insoluble en hidrocarburos parafínicos y soluble en compuestos aromáticos como el benceno; la segunda es descrita como una mezcla de resinas y otros hidrocarburos. Estas dos fases constituyen un sistema coloidal. En este trabajo se presentan los resultados experimentales del efecto de la proporción de asfaltenos y resinas en la viscosidad de tales crudos, con vista a su aplicación como materiales imprimadores. Los experimentos se realizaron en un reactor batch marca Parr en una atmósfera de nitrógeno y empleando n-heptano como disolvente. Una vez precipitados los asfaltenos a partir de las muestras utilizadas $y$, seguidamente, de la fracción de maltenos obtenida, se separaron las resinas. Al comparar los resultados obtenidos, se encontró que los asfaltenos eran responsables de las características estructurales y de consistencia del vehículo, mientras las resinas le proporcionan propiedades aglutinantes y los aceites malténicos actúan como disolventes.

Palabras clave: imprimadores asfálticos, crudos extrapesados, asfaltenos, resinas y viscosidad.

\begin{abstract}
SUMMARY
The bituminous crude from the Machete, Venezuela, area, which has such a fluid consistency that it falls outside the normal scope of the ASTM D-5 (1) penetration test, exceeding the 30- $\mathrm{mm}$ ceiling specified in that standard, and can be used as an asphalt primer. Like other asphalt products, these materials are - chemically speaking - a mix of numerous naphthenic, paraffinic and aromatic hydrocarbons and heterocyclic compounds containing sulphur, nitrogen, oxygen and so on. They have a dense and a malthene oil phase which, along with the natural hydrocarbons additives used in these products, acts as a volatile fluidizer. The former is described as a mix of asphaltenes: complex, high molecular weight substances that are insoluble in paraffinic hydrocarbons and soluble in aromatic compounds such as benzene. The malthene oil phase, in turn, consists in a mix of resins and hydrocarbons and together the two constitute a colloidal system. The experiments discussed in the present paper were conducted to determine the effect of the proportion of asphaltenes and resin oils on the viscosity of such bituminous crude emulsions, with a view to their use as primers. These experiments were run in a Parr batch reactor in a nitrogen atmosphere using n-heptane as a solvent. The resins were separated after the asphaltenes precipitated from the samples and subsequently from the malthene fraction obtained. The results showed that the asphaltenes account for the structural characteristics and consistency of the medium and the resin oils for its cohesive properties; the malthene oils act as solvents.
\end{abstract}

Keywords: asphalt primers, bituminous crude oil, asphaltenes, resins, viscosity.

\footnotetext{
(*) Dpto. Construcciones Arquitectónicas II, Univ. de Sevilla (ESPAÑA).

${ }^{(* *)}$ Fac. Cì̀ncias. Escuela de Química. Univ. Central de Venezuela (VENEZUELA).

Persona de contacto/Corresponding author: gmarmar@us.es (G. Márquéz).
} 


\section{INTRODUCCIÓN}

Conforme a la respectiva Norma Básica de la Edificación NBE-QB-90 (2), a fin de establecer las condiciones exigibles a las cubiertas de obras de construcción de edificios de nueva planta, de ampliación y de reforma que se realicen con materiales bituminosos: las pinturas bituminosas son, junto con las emulsiones asfálticas, productos líquidos utilizados para la imprimación y la preparación de las distintas superficies que vayan a impermeabilizarse con el fin de mejorar la adherencia del material impermeabilizante con el soporte. En esta norma de obligado cumplimiento, a sustituir por la NBE-IQ «Impermeabilización de Cubiertas», las pinturas bituminosas de imprimación se clasifican en materiales de base asfáltica (Tipo I) y de base alquitrán (Tipo II).

Las pinturas asfálticas de imprimación, designadas con las siglas PI seguidas de un guión, del correspondiente número romano y de la respectiva referencia (3), son aplicadas en capa fina, que al secarse forma una película sólida continua, mediante brocha, cepillo o pulverizador. Su misión consiste en entrar en contacto con la superficie del soporte para aumentar su adherencia y conseguir autoprotección. La aplicación debe realizarse en todas las zonas en las que la impermeabilización deba adherirse y en los remates.

Se trata, pues, de un material de suma importancia para el sector de la construcción por sus propiedades de consistencia, adhesividad, impermeabilidad, durabilidad y bajo costo (4). Aunque las citadas pinturas asfálticas se obtienen, generalmente, diluyendo o mezclando los betunes asfálticos semisólidos con subproductos líquidos, casi tan fluidos como el agua, obtenidos de la destilación de determinados crudos de petróleo; es posible usar directamente los petróleos asfálticos que cumplan con unas especificaciones determinadas. En tal sentido, parte del asfalto líquido que se utiliza, desde épocas pasadas, es el crudo bituminoso, el cual se encuentra en yacimientos naturales y pueden explotarse sin necesidad de operaciones industriales de ningún tipo para su preparación. Estos yacimientos se han producido a partir del petróleo por un proceso natural de evaporación de las fracciones volátiles enriqueciendo las pesadas. A este producto se le llama frecuentemente asfalto de lago. Los yacimientos más importantes de productos asfálticos líquidos naturales se explotan en el sur de los Estados Unidos de América y en el norte de Venezuela (5).

Más concretamente, los crudos venezolanos de la franja del Orinoco (área Machete) se caracterizan por tener una alta viscosidad y un alto contenido de aromáticos y asfaltenos. Estos productos líquidos, no refinables y económicamente poco atractivos, pueden ser considerados unos "asfaltos naturales de curado lento" cuyas características permiten su fácil aplicación en espacios abiertos sin tener que calentarlos a elevadas temperaturas, e incluso en frío, como base de pinturas de imprimación de elevada capacidad de penetración, añadiéndoles cantidades de disolventes volátiles (gasolina, queroseno...) con el objeto incrementar el grado de fluidez del crudo extrapesado. Una vez puesto el producto fluidificado en

\section{INTRODUCTION}

According to the basic Spanish Building Standard NBE-QB-90 (2) -which establishes the requirements to be met by roofs containing bituminous materials in new construction, enlargements and refurbishments-, bituminous paints, together with asphalt emulsions, are liquid products used to prime and prepare surfaces to be weatherproofed for their capacity to improve the adherence of the weatherproofing to the substrate. In this mandatory standard, to be superseded by NBE-IQ "roof weatherproofing", bituminous primers are classified as (Type I) asphalt base materials and (Type II) tar base materials.

Asphalt primers, which are designated with the letters PI followed by a dash, the respective roman numeral and reference (3), are brushed or sprayed on to the surface to be primed as a thin layer that dries to form a continuous solid film. The purpose of this layer is to bind to the underlying surface to enhance adherence and selfprotection. It should be applied on all areas to be weatherproofed, including areas under flashings, upstands and so on.

It is, then, a material of cardinal importance for the construction industry for its consistency, adherence, watertightnesss, durability and low cost (4). Although such asphalt primers are generally obtained by diluting or mixing semi-solid asphalt tar with liquid by-products - nearly as fluid as water- obtained from distilling certain types of crude oil, asphaltic petroleum conforming to a number of specifications may be used directly for this purpose. In this regard, part of the liquid asphalt that has been used for many years is bituminous crude found in natural deposits that requires no industrial processing or preparation whatsoever. Such deposits are formed when the lighter fractions of crude oil that has seeped to the surface of the earth are driven off by the action of sun and wind. The largest deposits of this nature, known as lake asphalt, in which the concentration of the denser fraction materials is higher, are located in the southern United States and northern Venezuela (5).

More specifically, the Venezuelan crude along the Orinoco strip (Machete area) is characterized by high viscosity and a high aromatic and asphaltene content. These nonrefinable and economically unattractive liquid materials, regarded to be "slow cured natural asphalts", can be readily applied in open areas as primer coats with excellent penetration properties, with no need for heating to high temperatures or even at all. Volatile solvents (gasoline, kerosene...) are usually added to enhance their fluidity. When the fluidized product, with viscosity values of from 
la obra con valores de viscosidad a $25^{\circ} \mathrm{C}$ desde 25 a 75 s Saybolt Furol, medida según método ASTM D-2171 (6), parte de los fluidificantes se evapora y surge una película sólida adherida al substrato.

Químicamente, estos productos asfálticos naturales son una mezcla compleja de hidrocarburos (4), por lo que del 90 al $95 \%$ del peso de los mismos está compuesto por carbono e hidrógeno. Los componentes de dicha mezcla se agrupan en cuatro fracciones: carboides y carbenos, por un lado, en cantidades de hasta el $2 \%$, y las fracciones principales, asfaltenos y maltenos, por otro. Los denominados maltenos tienen pesos moleculares de $700 \mathrm{a}$ 4.000; a su vez, los aceites malténicos puede subdividirse en tres partes: parafinas y naftenos con pesos de 600 a 1.000 , resinas de 1.000 a 2.000 (formaldehído, fenol...) e hidrocarburos aromáticos de 2000 a 4000 . Los asfaltenos o fracción pesada y de alta polaridad, cuyo peso molecular oscila de 2.000 a 7.000, es una mezcla que contiene compuestos aromáticos de peso molecular entre 2.000-5.000, hidrocarburos saturados, compuestos organometálicos con níquel, vanadio o hierro y heterociclos con átomos de azufre, oxígeno y nitrógeno (por ejemplo, piridina). Además de éstos, contienen hidrocarburos aromáticos volátiles (benceno, tolueno u otros), ácidos carboxílicos y fenólicos e hidrocarburos aromáticos condensados como el naftaleno, antraceno, benzantraceno, naftaceno, pentafeno, etc.

En el aspecto estructural los productos asfálticos líquidos, también denominados asfaltos rebajados o cutbacks, están considerados, de hecho, como unos materiales coloidales constituidos por diferentes micelas inversas de tamaños de varios miles de angstroms (asfaltenos) en el seno de una fase continua oleosa (maltenos) que dispersa a los anteriores (7). En concreto, las moléculas polares (asfaltenos y resinas) forman asociaciones intermoleculares temporales (Figura 1) a modo de redes tridimensionales más o menos desarrolladas que condicionan la viscosidad de estos productos; así como las no polares (hidrocarburos aromáticos y saturados) forman el cuerpo alrededor de las mencionada redes (8). Dichas moléculas, polares o no, se distribuyen de forma homogénea.
25 to 75 Saybolt Furol seconds at $25{ }^{\circ} \mathrm{C}$, measured as described in standard ASTM D-2171 (6), is applied to the substrate, part of the fluidizers evaporates to leave a solid film closely bound to the substrate.

Such natural asphalt materials are a complex chemical mix of hydrocarbons (4), with carbon and hydrogen accounting for 90 to $95 \%$ of their weight. The mix can be divided into four component fractions: on the one hand carboids and carbenes, amounting to up to $2 \%$, and the main fractions, asphaltenes and malthenes, on the other. Malthenes have molecular weights of from 700 to 4,000. Malthene oils, in turn, can be subdivided into three classes: paraffins and naphthenes with weights ranging from 600 to 1,000 , resins from 1,000 to 2,000 (formaldehyde, phenol...) and aromatic hydrocarbons with weights of 2,000 to 4000. The asphaltenes, the dense, high polarity fraction with molecular weights of between 2,000 and 7,000 , comprise a mix containing aromatic compounds with molecular weights ranging from 2,000 to 5,000, saturated hydrocarbons, organometallic compounds containing nickel, vanadium or iron, and heterocyclic substances with sulphur, oxygen and nitrogen atoms (pyridine, for instance). In addition, they contain volatile aromatic hydrocarbons (benzene, toluene or others), carboxylic and phenolic acids and condensed aromatic hydrocarbons such as naphthalene, anthracene, benzanthracene, naphthacene, pentaphene and so forth.

Structurally, liquid asphalt products, also known as reduced asphalt materials or cutbacks, are actually regarded to be colloids comprising different inverse micelles measuring several thousand angstroms (asphaltenes) that are uniformly distributed in an oily and continuous dispersion medium (malthene oils) (7). Specifically, the polar molecules (asphaltenes and resins) form temporary intermolecular associations (Figure 1) in more or less developed three-dimensional webs, to which these materials owe their viscosity, and are enveloped by the non-polar components (aromatic and saturated hydrocarbons) (8). All these molecules, polar or otherwise, are evenly distributed.

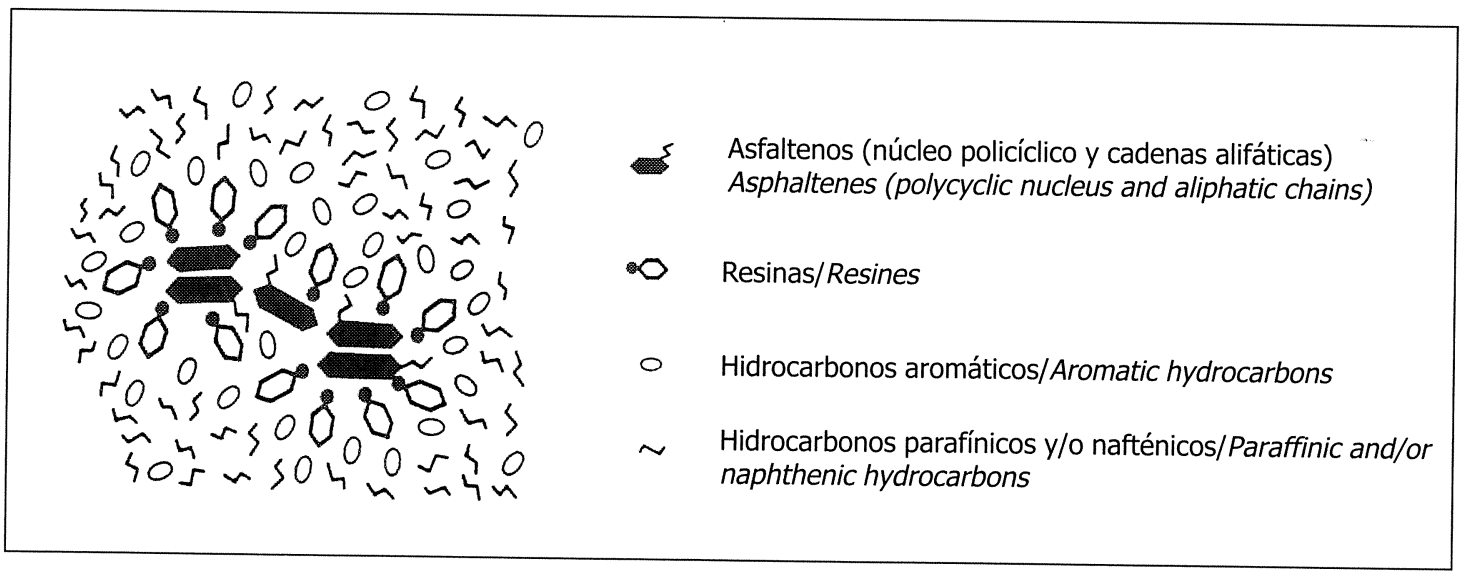

Figura 1.- Representación de la asociación molecular entre resinas y asfaltenos, tomado de otros autores (9). Figure 1. Molecular association between resins and asphaltenes, adapted from other authors (9). 
Durante los últimos años varios proyectos de investigación se han interesado en desarrollar un conocimiento fundamental y formal sobre estos productos para encontrar alternativas de aprovechamiento de estos materiales. En ese sentido, las propiedades fisicoquímicas de los mismos pueden permitirles ser suficientemente dúctiles, maleables y reométricamente aptos para su aplicación como capa de fondo o imprimadores en cubiertas impermeabilizantes de edificaciones, a fin de satisfacer la creciente demanda mundial de los mismos. Por otro lado, no debe olvidarse que estos materiales pueden ser susceptibles a los cambios de temperatura, sufrir envejecimiento por intemperismo o ser afectados por la oxidación y la fotodegradación, lo que limita su rango de utilidad. Por todas estas razones, estos productos suelen ser aditivados o modificados para mejorar dichas propiedades.

El objetivo general de este trabajo es determinar $y$, de alguna manera, cuantificar la influencia que los componentes del producto asfáltico líquido, en particular los asfaltenos y resinas, tienen sobre una de las propiedades más importantes del mismo: la viscosidad. Es de mucha utilidad un amplio conocimiento de la constitución y composición química de los asfaltos líquidos, puesto que el control de sus propiedades reológicas permite obtener un mejor funcionamiento en las citadas impermeabilizaciones.

\section{EXPERIMENTAL}

Como ya se ha referido en la introducción, se utilizó el crudo bituminoso Machete para la obtención de las resinas y asfaltenos. Como operación previa se produjo el secado de dicho crudo, tras disolverlo en exceso de tolueno, mediante destilación hasta eliminar toda la mezcla azeotrópica de agua y disolvente a $78^{\circ} \mathrm{C}$ de temperatura. Seguidamente, las principales fracciones del producto asfáltico líquido fueron separadas usando la diferente solubilidad de sus moléculas en un disolvente adecuado. En primer lugar, se realizó la precipitación de los asfaltenos a partir del crudo seco. Con respecto al disolvente usado para la separación de los asfaltenos se ha optado por usar n-heptano grado HPLC, debido a que la precipitación es fácil de lograr a presión atmosférica y la confiabilidad experimental es mejor (10); aunque también puede realizarse convenientemente por medio de otros hidrocarburos parafínicos de bajo peso molecular. Si se usa n-heptano los asfaltenos son de más alto peso molecular y mayor polaridad que si se utiliza n-pentano, aunque al aumentar la temperatura con n-pentano se precipita una mayor cantidad de asfaltenos que con n-heptano (11). Por otro lado, y a efectos de obtener realmente las máximas concentraciones de asfaltenos (12), se empleó una relación volumétrica entre el n-heptano agregado y el crudo seco de $60: 1$.

Para ello se procedió a cargar al reactor batch con $1 \mathrm{~g}$ de muestra de crudo extrapesado y aproximadamente $1 \mathrm{ml}$ de benceno por cada $100 \mathrm{ml}$ de $\mathrm{n}$-heptano, operándose con agitación constante durante 1 hora, a la temperatura de $60^{\circ} \mathrm{C}$, y un tiempo de reposo de 12 horas. Como resultado de la experimentación, se obtiene un material pulverulento de color café oscuro o negro, los asfaltenos
A number of research projects has been conducted in recent years to acquire a fundamental and formal understanding of these materials in pursuit of possible alternative uses. In this regard, their physical-chemical properties may make them sufficiently ductile and malleable to be rheometrically apt for use as primers in weatherproofed roofs, in which case they may help meet the increasing world-wide demand for such products. Conversely, however, these materials may be sensitive to temperature changes, age as a result of weathering or undergo oxidation or photodegradation, all of which would limit their range of use. For all these reasons such materials are usually altered with additives or otherwise modified to enhance their beneficial properties.

The overall purpose of the present study was to determine and quantify, as far as possible, the effect of the components of liquid asphalt material, particularly asphaltenes and resins, on one of its most important properties: viscosity. A broad understanding of the chemical composition of liquid asphalt materials is extremely useful, inasmuch as control of their rheological properties will lead to higher performing and more effective weatherproofing.

\section{EXPERIMENTAL}

As noted in the introduction, Machete bituminous crude was used to obtain resins and asphaltenes. A preliminary operation involved dissolving the crude in excess toluene and distillation-drying at $78{ }^{\circ} \mathrm{C}$ to remove the entire azeotropic mixture of water and solvent. The main fractions of the liquid asphalt material were then separated by differential dissolution. First, the asphaltenes were precipitated out of the dry crude with HPLC-grade nheptane, a compound ensuring ready precipitation at atmospheric pressure and high experimental reliability (10), although this operation can also be suitably performed with low molecular weight paraffinic hydrocarbons. The asphaltenes obtained with n-heptane have a higher molecular weight and greater polarity than those separated with n-pentane, although in the latter case, due to the higher temperatures generated, a larger amount of asphaltenes precipitate than when n-heptane is used (11). The n-heptane / dry crude ratio used, by volume, was 60:1 to obtain the maximum asphaltene concentration (12).

More precisely, the procedure involved loading the batch reactor with a 1-g sample of crude and approximately 1 $\mathrm{ml}$ of benzene per $100 \mathrm{ml}$ of $\mathrm{n}$-heptane; stirring the mixture constantly for 1 hour at $60^{\circ} \mathrm{C}$ and then letting it stand for a further 12 hours. The result was a dark brown or black powdery material - the precipitated asphaltenes- and a supernatant liquor containing aromatic oils, saturated 
precipitados, y un sobrenadante que contiene aceites aromáticos, hidrocarburos saturados y resinas. Si bien el método normalizado ASTM-D-3279 (13) recomienda un tiempo de contacto de veinte minutos bajo condiciones de reflujo, a tiempos de contacto mayores no sólo se logran obtener rendimientos estables de asfaltenos y unos resultados más reproducibles, sino que también se asegura que se remuevan las resinas adsorbidas sobre éstos, aumentando la pureza de los mismos (14). Dentro del subproducto obtenido por el domo del reactor, se arrastra una pequeña cantidad de asfaltenos en forma de finos, que se deben filtrar. Finalmente, dichos asfaltenos se enjuagaron con $n$-heptano varias veces hasta que el líquido obtenido en la filtración fuera incoloro.

$A$ posteriori, el citado subproducto se rotaevaporó a vacío para obtener los maltenos secos. Dicho precipitado se sometió a una extracción Soxhlet con n-heptano, a presión atmosférica, con el fin de separar las resinas. Se disolvieron $15 \mathrm{~g}$ de maltenos en $400 \mathrm{ml}$ de solvente, a la solución se añadieron unos $700 \mathrm{~g}$ de sílica-alúmina previamente activada a $120^{\circ} \mathrm{C}$ durante 2 horas. Dicha mezcla se agitó agregando pequeñas cantidades de solvente hasta que éste adquiría una coloración amarilla; entonces se decanta el n-heptano y se repetía la operación hasta que este emergiera transparente. La fracción de las resinas, una vez precipitada, se secaba a presión reducida. Luego, la solución proveniente de la mencionada extracción se rotaevaporaba a baja presión y, por último, los restantes maltenos también eran secados al vacío.

Para el desarrollo experimental de este trabajo, se emplearon los equipos que se describen a continuación: un reactor batch discontinuo marca Parr con una capacidad de $2.000 \mathrm{ml}$, un sistema de agitación, control de temperatura, evacuación de gases y del producto líquido, control de presión, enfriamiento con aire y un sistema de drenado para la obtención de los asfaltenos. Adicionalmente, se utilizó un papel filtro tipo Whatman 934 $\mathrm{AH}$ núm. $1827-110$ y 1,5 micras de tamaño de poro.

Para determinar la viscosidad dinámica del crudo Machete, así como de los crudos sintéticos preparados, se ha utilizado un viscosímetro rotacional Haake modelo RV3 con cabezal de medición MDK y sistemas sensores SVI y SVII. Dicho aparato operó mediante preselección de la tasa de corte y las mediciones en el mismo se basan en el hecho de que la viscosidad absoluta es igual a un parámetro, previamente tabulado, dependiente del equipo empleado multiplicado por el cociente entre el valor de la escala proporcional al torque del rotor y el número de revoluciones del mismo. Antes de cada determinación de viscosidad, las muestras de crudos sintéticos a $55^{\circ} \mathrm{C}$ fueron sometidas a ultrasonido durante una hora con calentamiento a fin de garantizar, en todo lo posible, la homogeneidad de dichas muestras.

En cuanto a las caracterizaciones reológicas de las soluciones de crudo Machete y sus fracciones en xileno, a una temperatura de $28^{\circ} \mathrm{C}$, se ha hecho uso de un viscosímetro rotacional Contraves modelo Lowshear 30 dotado con pantalla digital y un detector fotoeléctrico acoplado a un imán multipolar a modo de amplificador de compensación. Este equipo permite medir, con gran exactitud, hydrocarbons and resins. While the method described in standard ASTM D-3279 (13) recommends a twenty-minute reflux time, longer times provide not only for stable asphaltene yields and more reproducible results, but also ensure that the resins adsorbed on the asphaltenes are removed, enhancing purity (14). The small amounts of tiny grain-shaped asphaltene particles deposited on the reactor dome with other by-products had to be filtered. Finally, the asphaltenes were rinsed with n-heptane several times until a colourless filtrate was obtained.

This filtrate was subsequently vacuum evaporated to obtain dry malthenes that were subjected to Soxhlet extraction with n-heptane at atmospheric pressure to separate the resins. Fifteen $g$ of malthenes were dissolved in $400 \mathrm{ml}$ of solvent, to which $700 \mathrm{~g}$ of silica-alumina, previously activated at $120^{\circ} \mathrm{C}$ for two hours, were added. This mix was stirred and small amounts of solvent added until it turned yellow; the n-heptane was then poured off and the operation repeated until a transparent mix was obtained. After precipitating, the resin fraction was vacuum dried at low pressure. The solution from the extraction was subsequently evaporated at low pressure; lastly, the remaining malthenes were also vacuum dried.

The equipment described below was used for the experimental part of this study: the asphaltenes were separated with a 2,000- $\mathrm{ml}$ Parr discontinuous batch reactor fitted with a stirring system, temperature control, gas and liquid evacuation facility, pressure control, air cooling and a draining system. Whatman $934 \mathrm{AH}$ filter paper with a pore size of 1.5 microns, ref. 1827-110, was also used.

\begin{abstract}
A Haake model RV3 rotational viscometer with an MDK measuring head and SVI and SVII sensors was used to determine the dynamic viscosity of both the Machete crude and the synthetic crude oils prepared for the study. In this experiment, the shear rate was pre-selected on the above device. Its measurements are based on the fact that absolute viscosity is equal to a parameter - whose values are tabulated and depend on the equipment used - multiplied by the quotient resulting from dividing the scale value proportional to the rotor torque by the number of revolutions. Before determining the viscosity values, the samples of synthetic crude were subjected to ultrasound treatment at $55^{\circ} \mathrm{C}$ for one hour to guarantee their homogeneity, as far as possible.
\end{abstract}

The Machete crude solutions and their fractions in xylene were rheologically characterized at $28{ }^{\circ} \mathrm{C}$ with a Contraves model Lowshear 30 rotational viscometer equipped with a digital screen and a compensation amplifier consisting in a photoelectric detector connected to a multi-polar magnet. This device is able to accurately measure dynamic viscosity over a range of from one 
viscosidades dinámicas en un intervalo de una millonésimo a mil poises. El dispositivo permite trabajar con pequeñas cantidades de muestra (aproximadamente dos gramos), cubriendo "velocidades de cizalla" desde un centésimo a 250 segundos recíprocos.

Por último, la densidad o gravedad API del crudo Machete se determinó, según norma ASTM D-2041 (15), utilizando un dispositivo Rice que incluía un conjunto de elementos necesarios: vibrador, picnómetro de vacío, bomba de vacio, juego de filtración, balanza electrónica y un manómetro de presión residual compuesto de un tubo en "U" cerrado en un extremo y montado sobre una cúpula de vidrio conectada al recipiente de vacío.

\section{RESULTADOS}

Dos propiedades muy importantes del crudo estudiado son su viscosidad cinemática (96620 s Saybolt Furol a $55^{\circ} \mathrm{C}$ ) y su elevada densidad (gravedad API igual a $9,6^{\circ}$ ), consecuencia directa de su alto tanto por ciento de resinas y asfaltenos. Disminuye con la temperatura a la que se encontraba el petróleo en su ambiente de generación, lo que implica que los yacimientos profundos, enterrados a mayores profundidades, contendrán crudos menos densos. Igualmente, la composición química del crudo Machete (porcentaje en peso) resultó ser: maltenos $(77,9 \%)$, resinas $(56,9 \%)$ y asfaltenos $(22,1 \%)$.

En los reogramas obtenidos a partir de los crudos sintéticos preparados y de las diferentes disoluciones en xileno de las fracciones constituyentes del petróleo Machete, las medidas de "esfuerzo cortante" y "velocidad de cizalla" (a distintos valores de ambos) indican una proporcionalidad directa entre estas magnitudes en el intervalo de temperatura de 28 a $55^{\circ} \mathrm{C}$. Sin embargo, muy probablemente no se trate de fluidos newtonianos, puesto que los productos petrolíferos suelen presentar un comportamiento tixotrópico (16).

En la Figura 2 se representan los valores respectivos de la viscosidad frente a concentración de tres series de disoluciones de asfaltenos, resinas y, por último, del conjunto de hidrocarburos saturados y aromáticos volátiles. Las medidas se hicieron en presencia de dimetilbenceno como disolvente, cuya viscosidad a la temperatura de operación $\left(28^{\circ} \mathrm{C}\right.$ ) es de $0,64 \mathrm{cp}$. Se observa claramente que los asfaltenos tienen mucho mayor responsabilidad en los altos valores de la viscosidad de las mezclas con xileno analizadas que la de cualquiera de las otras fracciones. Desafortunadamente, debido a problemas de solubilidad, no fue posible trabajar a concentraciones de asfaltenos superiores al $16 \%$ en peso. No obstante, existía una variación exponencial de la viscosidad con la concentración de asfaltenos. También se aprecia en esta misma figura que dicha propiedad varía en menor medida con la concentración de resinas, aunque esa influencia es bastante menos pronunciada. Para finalizar, el lugar geométrico de los puntos experimentales que relacionan la concentración de los aceites malténicos con la viscosidad puede aproximarse mediante una recta de muy baja pendiente y alto grado de correlación. millionth of a poise to one thousand poises. Moreover, small size samples (approximately two grams) can be used, covering "shear rates" from a hundredth of a reciprocal second to two hundred and fifty reciprocal seconds.

Lastly, the density or API gravity of Machete crude was determined as specified in standard ASTM D-2041 (15), using a Rice device fitted with all the necessary components: vibrator, vacuum pycnometer, vacuum pump, filter set, electronic scales and residual pressure manometer: a "U"-shaped pipe closed at one end and mounted on a glass blister connected to an evacuation tank.

\section{RESULTS}

Two very important properties of the crude studied, its kinematic viscosity (96620 Saybolt second universal at $55^{\circ} \mathrm{C}$ ) and its high density (API gravity 9.6 ), are both a direct result of its high resin and asphaltene content. This content declines at the temperature at which the oil formed, inferring that crude density is lower in very deep deposits. Similarly, the chemical composition of Machete crude oil (percentage by weight) proved to be: malthenes (77.9\%), resins (56.9\%) and asphaltense (22.1\%).

In the rheograms obtained from the synthetic crude oils prepared and the different xylene solutions of Machete oil, the shear stress and shear rate measurements (at different values of the two) proved to be directly proportional at temperatures ranging from 28 to $55^{\circ} \mathrm{C}$. Nonetheless, these are unlikely to be Newtonian fluids because petroleum products tend to exhibit thixotropic behaviour

Figure 2 shows the respective viscosity - concentration curves for three series of solutions- asphaltene, resins and the group of saturated and volatile aromatic hydrocarbons. The measurements were taken in the presence of dimethylbenzene as the solvent, whose viscosity at the working temperature $\left(28^{\circ} \mathrm{C}\right)$ is $0.64 \mathrm{cp}$. The high viscosity values in the xylene mixes analyzed were clearly due to the asphaltenes much more than to any of the other fractions. For reasons of solubility, however, it was unfortunately not possible to work at asphaltene concentrations of over $16 \%$ by weight. Nonetheless, viscosity was observed to vary exponentially with asphaltene concentration. The figure shows that viscosity also varied with resin concentration, but much less acutely. Finally, the geometric distribution of the experimental points relating malthene oil concentration to viscosity nearly exactly defines a very slightly sloping and highly correlated straight line. 


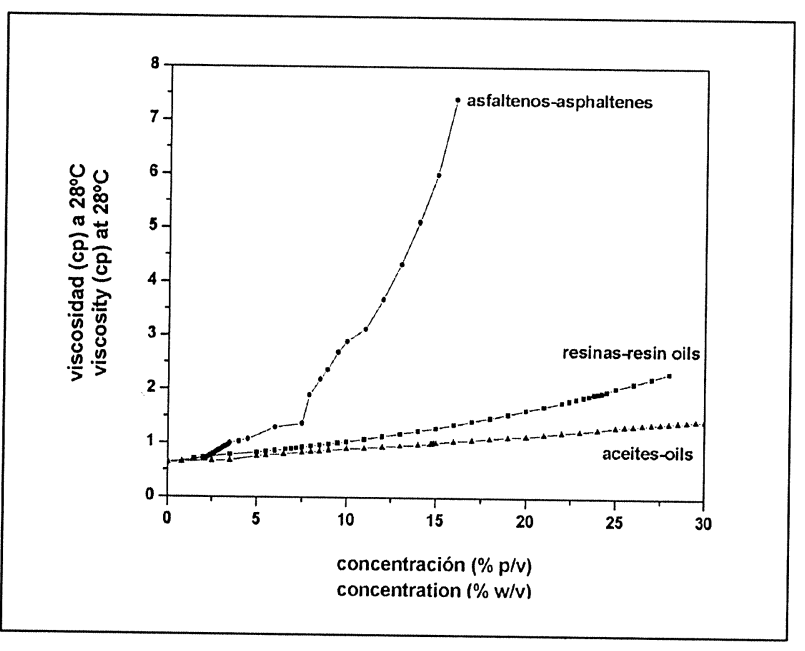

Figura 2.- Viscosidades a $28^{\circ} \mathrm{C}$ de diferentes disoluciones de asfaltenos, resinas y aceites en xileno.

Figure 2.- Viscosity at $28^{\circ} \mathrm{C}$ of different aspahltenes, resins and oils in xylene.

La Figura 3 incluye sendas gráficas del logaritmo de la viscosidad frente al porcentaje ponderal de asfaltenos de dos series de crudos sintéticos a $55^{\circ} \mathrm{C}$. Estas muestras se preparon partiendo de las fracciones separadas del crudo Machete, de tal manera que fueran constantes, respectivamente, las relaciones de resinas a maltenos y de asfaltenos a resinas. La información obtenida muestra que la viscosidad de estas disoluciones con presencia de resinas y asfaltenos es significativamente mayor que lo esperado de acuerdo con las tendencias previamente evidenciadas de ambos por sí solos. Asimismo, la influencia de la proporción de asfaltenos en la viscosidad de estas últimas mezclas estudiadas es mayor que la causada por los mismos en ausencia de resinas.

\section{DISCUSIÓN}

La consistencia de un producto asfáltico es el grado de fluidez que tiene el mismo a una determinada temperatura. La viscosidad es la resistencia del material a fluir. La situación ideal es aquélla de aquel material que mantiene su consistencia en un amplio intervalo de temperatura, es decir, su susceptibilidad térmica es baja.

Las investigaciones realizadas señalan que existen diversos factores responsables de la viscosidad de dichos fluidos. Considerando la literatura en el caso de mezclas bituminosas complejas, la viscosidad sigue algunas tendencias generales: disminuye con el aumento de temperatura (17), aumenta con el incremento de la presión o la densidad (18) y, sobre todo, depende de la estructura molecular de los componentes. De acuerdo con lo anterior, se ha encontrado que, para los hidrocarburos, a mayor peso molecular y/o carácter cíclico, mayor valor de la viscosidad. Ello se explica porque el flujo se facilita con la mayor flexibilidad o posibilidad de deformación de las moléculas que presentan mayor número de grados de libertad (19). A tal respecto, la presencia de determinados grupos funcionales capaces de formar enlaces tipo

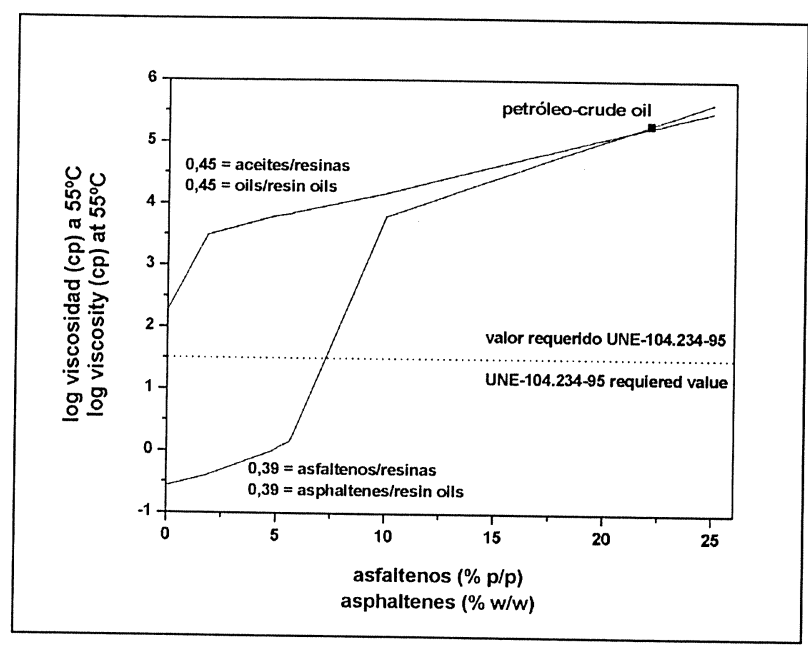

Figura 3.- Viscosidades a $55^{\circ} \mathrm{C}$ de distintas mezclas sintéticas a relaciones constantes de resinas a asfaltenos y de aceites a resinas.

Figure 3.- Viscosity at $55{ }^{\circ} \mathrm{C}$ of different synthetic mixes with constant resin to asphaltene and oil to resin ratios.

The graph in Figure 3 plots the log of viscosity values against the log of the weighted percentage of asphaltenes in two series of synthetic crude oils at $55^{\circ} \mathrm{C}$. These samples were prepared from the fractions separated from Machete crude in such a way that the resin-malthene and asphaltene-resin ratios were constant. The information obtained shows that the viscosity of these resin- and asphaltene-containing solutions is significantly greater than would be expected on the grounds of the patterns observed previously for the two substances alone. Similarly, the effect of the proportion of asphaltenes on the viscosity of these mixes is greater than their effect in the absence of the resins.

\section{DISCUSSION}

The consistency of an asphalt material is its degree of fluidity at a given temperature. Viscosity is the resistance of the material to flow. The ideal material is one whose consistency is constant over a wide temperature range, i.e., one with low thermal susceptibility.

Research has shown that a number of factors is responsible for viscosity in such fluids. According to the literature on complex coated macadam, viscosity follows certain general trends: it declines with increasing temperature (17), rises with growing pressure or density (18) and is highly dependent on the molecular structure of the components. In this vein, in hydrocarbons the greater the molecular weight and/or the more cyclic the structure, the higher are the viscosity values. This can be explained by the greater flexibility or deformability of molecules with larger numbers of degrees of freedom (19). In this respect, the presence of certain functional groups able to form 
puentes de hidrógeno, que dan lugar a asociaciones intermoleculares de bastante tamaño, provoca un incremento importante de la viscosidad (19).

Para explicar el comportamiento viscoso de los productos asfálticos líquidos, éstos deben considerarse como una disolución coloidal, donde un grupo de moléculas más pesadas y polares (asfaltenos) están rodeadas por otras moléculas polares más ligeras (resinas), formando micelas inversas, sin que exista una separación entre aquéllas, sino una transición, finalmente, ocupando el espacio restante los aceites nafténicos, parafínicos y aromáticos (20). Estos últimos constituyen el medio dispersante de baja polaridad o fase continua.

La microestructura de los crudos sintéticos estudiados queda definida entonces por la cantidad de micelas, su distribución de tamaños y por las interacciones fisicoquímicas entre ellas. La fracción de los asfaltenos se presenta a modo de láminas paralelas unidas por fuerzas fisicoquímicas y compuestas por núcleos aromáticos condensados sustituidos por grupos alifáticos, nafténicos y heterocíclicos (21). Las resinas poseen estructuras parecidas a las de los asfaltenos pero tienen menor tamaño y una proporción mayor de cadenas parafínicas como sustituyentes de los anillos aromáticos. A causa de ello, las resinas son una fase de polaridad intermedia que sirven como interfase entre los asfaltenos polares, a los que recubren, dando lugar a las mencionadas micelas, y el resto de la matriz del medio oleoso que, generalmente, posee una alta relación entre parafinas y aromáticos no polares (22). Los asfaltenos precipitarían de no ser por la presencia de esta capa de resinas que los rodean (23).

\section{CONCLUSIONES}

Los resultados obtenidos en el presente trabajo indican que la alta viscosidad del crudo Machete se explica, fundamentalmente, por su contenido en asfaltenos, componentes que causan, por sí solos, un marcado aumento de la misma; en menor medida, dicho incremento puede ser atribuido a la acción de las resinas. Por último, los maltenos influyen mucho menos sobre esta propiedad; de lo cual se concluye que el comportamiento reológico de las muestras analizadas se explica en gran parte porque los asfaltenos forman asociaciones intermoleculares en un ambiente poco polar debido a la capacidad de los grupos funcionales oxhidrilos y aminos presentes en aquéllos para establecer enlaces tipo puentes de hidrógeno. Otra conclusión es que para lograr una disminución apreciable de la viscosidad de un producto asfáltico líquido es necesario aumentar la razón de maltenos a resinas.

Se concluye también que la presencia simultánea de asfaltenos y resinas causa un cierto efecto sinérgico sobre la viscosidad, este hecho pone de manifiesto el desarrollo de un fenómeno de asociación intramiscelar, mediante enlaces tipo puentes de hidrógeno, entre asfaltenos y resinas, puesto que se sabe que dicha interacción da como resultado unas micelas inversas, termodinámicamente estables, de modo que los grupos hidrófilos de las moléculas de resinas o monómeros queden libres del contacto con el medio oleoso, protegidas por los grupos hydrogen bonds that give rise to fairly large intermolecular associations raises viscosity values substantially (19).

The viscous behaviour of liquid asphalt products can be best understood when they are viewed as colloidal systems in which a group of heavier and more polar molecules (asphaltenes) are surrounded by lighter weight molecules (resins) to form highly compacted clusters of inverse micelles, while the scant space in between is occupied by naphthenic, paraffinic and aromatic oils (20). This last group constitutes the low polarity dispersion medium or continuous phase.

The microstructure of the synthetic crude oils studied is defined, therefore, by the number, distribution and size of the micelles and the physical-chemical interactions between them. The asphaltene fraction can be described as a series of parallel layers connected by physical-chemical forces and comprising condensed aromatic nuclei substituted with aliphatic, naphthenic and heterocyclic groups (21). The resins exhibit a similar structure but with a smaller size and a smaller proportion of paraffinic chains as substitutes on the aromatic rings. Consequently, the resins constitute an intermediate polarity phase that act as an interface between the polar asphaltenes, which they envelop forming the micelles, and the rest of the oily medium which usually has a high paraffin/non-polar aromatic compound ratio (22). If they were not surrounded by a layer of resins, the asphaltenes would certainly precipitate (23).

\section{CONCLUSIONS}

The results obtained in the present study indicate that the high viscosity of Machete crude is essentially due to its asphaltene content, a fraction that by itself accounts for much of the viscosity, although this property may also be partially attributed to resins. Lastly, malthenes have a much smaller effect on viscosity. According to these findings, the rheological behaviour of the samples analyzed can be largely explained by the intermolecular associations among asphaltenes. Such associations can be generated in a scantly polar environment thanks to the hydrogen bonds formed by their functional oxyhydryl groups and aminos. Another conclusion is that the malthene-resin ratio must be increased to appreciably reduce the viscosity of liquid asphalt materials.

Moreover, the simultaneous presence of asphaltenes and resins is observed to have a synergetic effect on viscosity. This finding is indicative of the development of intramicellar associations between asphaltenes and resins thanks to hydrogen bonding, an interaction known to give rise to inverse, thermodynamically stable micelles. The hydrophilic molecules in the resins or monomers are thereby protected from any contact with the oily medium by hydrophobic groups. These inverse micelles are in dynamic equilibrium with the monomers in the medium. 
hidrófobos. Dichas micelas inversas se encuentran en un equilibrio dinámico con los monómeros del medio. El aumento de la proporción de asfaltenos y resinas produce un ascenso brusco de la viscosidad, atribuible al mayor número y tamaño de dichas micelas $y$, por ende, a la contribución de las interacciones intermicelares. En concreto, las interacciones hidrodinámicas entre estas micelas inversas provocan incrementos de viscosidad motivados por la interferencia entre líneas de corriente relativas al flujo de dos micelas iguales próximas (24); aunque también debe tenerse en cuenta las interacciones entre micelas de distinto tamaño (25).

En definitiva, por lo expuesto, una disolución bituminosa coloidal es más viscosa a mayor contenido de asfaltenos y resinas, por consiguiente, resulta obligado añadir algún tipo de fluidificante al objeto de que el crudo estudiado adquiera las características que, según norma UNE 104.324, debe cumplir toda pintura de base asfáltica, empleada como material de imprimación para impermeabilizaciones.
The increase in the proportion of asphaltenes and resins prompts an abrupt rise in viscosity, attributable to the greater number and size of such micelles and, therefore, of intermicellar interactions. Specifically, hydrodynamic interactions between these inverse micelles cause increases in viscosity due to interference in the stream of the flow between two nearby and identical micelles (24), although account must also be taken of the interactions between micelles of different sizes (25).

Summarizing, for all the foregoing, the higher the asphaltene and resin content in a bituminous colloidal solution, the more viscous it will be. Consequently, some manner of fluidizer must be added for the crude studied to meet the requirements laid down in Spanish standard UNE 104.324 for all asphalt-base primers used in weatherproofing.

\section{BIBLIOGRAFÍA}

(1) ASTM D-5, Standard method test for penetration of bitominous materials, ASTM Book of Standards. Philadelphia, 1997.

(2) NBE QB-90, Norma Básica de la Edificación, Cubiertas con materiales bituminosos, 1990 (3) AENOR, Norma UNE 104-234, modificada en 1995, Impermeabilización. Materiales bituminosos y bituminosos modificados. Pinturas
bituminosas de imprimación, 1992. (4) The Asphalt Institute, Materiales asfálticos, mezclas, construcción y calidad, pp. 22-30, 40-73, 37-40, Productos Asfálticos S. A., Madrid,
1985. (5) W. L. Nelson, G. Thery, D. Noriega, Petróleos crudos de Venezuela y otros países, p. 9, Ed. Ministerio de Minas e Hidrocarburos, Caracas,
1959.

(6) ASTM D-2171, Standard method test for viscosity of asphalts by vacuum capillary viscometer, ASTM Book of Standards, Philadelphia, 1995.

(7) The Asphalt institute, Manual del Asfalto, pp. 18-26, 70-82, 146-148, 271-284. Productos Asfálticos S. A. Madrid, 1962.

(8) R. B. Long, The concept of asphaltenes, pp. 53-60, American Chemical Society Editions. Washington D.C., 1981.

(9) J. P. Pfeiffer, R. N. Saal, «Asphaltic bitumen as colloid system», J. Phys. Chem., no 44 (1949), pp. 139-149.

(10) M. Tojima, S. Suhara, M. Imamura, A. Furuta, «Chemistry of asphaltenes: some aspects», Catalog. Today, $n^{\circ} 43$ (1998), pp. $347-351$.

(11) B. Nielsen, Effects of the temperature and pressure on asphaltene particle size distribution in crude oils diluted with n-pentane, pp. 1-
9, University of Calgary Edit. Calgary, 1994.

(12) J. G. Speight, S. E. Moschopedis, 1994.

D. C., 1981.

(13) ASTM D-3279, Standard test method for n-heptane insolubles, ASTM Book of Standards, Philadelphia, 1997.

(14) J. G. Speight, The chemistry and technology of petroleum, pp. 23-29, Marcel Dekker Edit. New York., 1998.

(15) ASTM D-2041, Standard method test for specific gravity of bituminous mixtures. ASTM Book of Standards, Philadelphia, 1995.

(16) J. Mewis, «Thixotrophy, a general review», Journal of Non-newtonian Fluid Mechanics, n 6 (1979), pp. 1-20.

(17) A. W. Adamsom, «The difussional behavior and viscosity of liquid mixtures», Soc. Pet. Eng., n० 219 (1963), pp. 148-158.

(18) M. Bouldin, A. Collins, The Rheology and micro-structure of polymer asphalt blends, pp. 2-8, American Chemical Society Edit.,
Washington D.C., 1990. (19) J. G. Speight, S. Moschopedis, On the Molecular Nature of Petroleum Asphaltenes, pp. 10-17, American Chemical Society Edit.,
Washington D.C., 1981.

(20) J. Roussel, R. Boulet, Composition of crude oils and petroleum products. Characterization of crude oils and petroleum fractions: Petroleum Refinig, Vol. 1 (1995), pp. 1-84, Editions Technip, Paris.

(21) T. F. Yen, G. V. Chilingarian, Asphaltenes and asphalts: development in petroleum science, Elsevier Edit., Paris, 1994.

(22) V. León, «Nuevos enfoques sobre la visión molecular de un crudo pesado», Rev. Visión Tecnológica, Vol. 2, n 5 (1998), pp. $131-138$.
(23) A. Layrisse, E. González, F. Chirinos. Composición y características fisicoquímicas de crudos extrapesados. Revista Técnica INTEVEP,
Vol. 1, n 4 (1984), pp. 3-18.

(24) J. W. Goodwin. Colloid dispersions (1982), pp. 165-195. Royal Society Chemistry Edit. London.

(25) R. J. Hunter. Foundations of collid Sciences, Vol. I (1987), pp. 564-625. Oxford Sciences Publishing. Oxford. 